\title{
Assessment of Organic Fertilizer Usage by Garden Egg Farmers in Enugu State, Nigeria
}

\author{
Jane Mbolle Chah ${ }^{1}$, Irenonsen Oyaimare Uddin ${ }^{1}$, Ikedichukwu Odoh ${ }^{1}$ \\ ${ }^{1}$ University of Nigeria, Nsukka \\ Nsukka Road, 410001, Nsukka, Enugu State, Nigeria
}

DOI: $10.22178 /$ pos.50-1

JEL Classification: Q10

Received 17.07.2019

Accepted 28.09.2019

Published online 30.09.2019

Corresponding Author:

Irenonsen Oyaimare Uddin

uddinirenonsen@gmail.com

(C) 2019 The Authors. This article

is licensed under a Creative Commons

Attribution 4.0 License @ (1)

\begin{abstract}
The study was undertaken to assess organic fertilizer usage by garden egg farmers in Enugu State, Nigeria. The multistage sampling technique was used to select 80 garden egg farmers. Descriptive statistics and multiple regression analysis were used to analyse data for the study. The mean age of respondents was 39 years. Fifty-five percent $(55 \%)$ of respondents were married. The majority $(97.5 \%)$ of the respondents used farmyard manure while the average cost of organic fertilizer was 57372.73 . A lesser percentage $(7.5 \%$ ) of respondents in the study applied over $2000 \mathrm{~kg}$ of organic fertilizer per hectare with $40 \%$ applying twice per season. The perceived benefit of organic fertilizer was: improvement of soil fertility $(2.95 \pm 1.12)$, environment-friendly $(2.99 \pm$ 1.23). A constraint identified in the use of organic fertilizer was: slow effect $(2.12 \pm 1.43)$, Odorous nature $(2.06 \pm 1.28)$ and difficulty in the collection and handling of organic fertilizer $(2.72 \pm 1.03)$. The study among other things recommends that farmers be granted credits and extension services that will teach them the required skills in the handling and use of organic fertilizer.
\end{abstract}

Keywords: garden egg production; organic agriculture; organic fertilizer; soil improvement; soil conservation; vegetables.

\section{INTRODUCTION}

Vegetables (leafy and fruits) are broadly cultivated in most parts of sub-Saharan Africa, particularly, in the rural areas, and they constitute the most reasonable and feasible source of micronutrients in diets. Garden egg originated from Tropical Africa [11] and derives its name from the shape of the fruit of some varieties which are white and shaped like chicken eggs [5]. The importance of the garden-egg cannot be overemphasized. It is consumed on daily basis by rural and urban dwellers and also represents the main source of income for producing households in West Africa [6]. Nutritionally, garden egg contains water $(92.5 \%)$, protein $(1 \%)$, fat $(0.3 \%)$, and carbohydrates (6\%). They contain between 30 and $50 \%$ of iron (Fe), fiber, potassium (K), manganese $(\mathrm{Mn})$, copper $(\mathrm{Cu})$ and vitamins; thiamin (vitamin $\mathrm{B}_{1}$ ), $\mathrm{B}_{6}$, folate, magnesium and niacin. Egg-plant also contains phyto-nutrients such as nasunin and chlorogenic acid [19].

Degradation is widely acknowledged as a major factor limiting productivity of the sub-Saharan
African smallholder farming systems [10]. This degradation is particularly predominant in areas of rapid population growth, continuous cropping, restricted use of organic inputs and high application of mineral fertilizers [12]. The seriousness of the soil degradation problem in West Africa has been shown to directly relate to land productivity [8]. Agriculture-based livelihood systems in Nigeria are very vulnerable to food insecurity especially in the low-lying areas of coastal southsouth; the flood prone areas of the south-west; the erosion prone areas of the south-east; the flood plain of the Niger-Benue trough, and the semi-arid/sahel drought/desertification prone areas of the north. Land and soil degradation presents a serious threat to the overall attainment of the food production and security in Nigeria. To continue to feed the ever-growing Nigerian population, there is an urgent need for effective soil management practices for optimal crop yields in all the agro-ecological zones of the country.

Enugu agriculture is characterized by soil infertility, due to continuous and over-use of chemicals, 
use of inorganic fertilizer, continuous cropping and mixed cropping experienced in the state [21]. Increasingly high inputs of chemical fertilizers during last 50 years have not only left soils degraded, polluted and less productive but have also posed severe health and environmental hazards [17]. Further disadvantages according to them include:

1. Overuse can result in negative effects such as leaching, pollution of water resources destruction of microorganisms and beneficial insects, crop susceptibility to disease attack, acidification or alkalization of the soil, or reduction in soil fertility, all of which cause irreparable damage to the overall ecosystem.

2. Oversupply of nitrogen leads to softening of plant tissue resulting in increased susceptibility to diseases and pests.

3 . They reduce the colonization of plant roots with mycorrihizae and inhibit symbiotic nitrogen fixation by Rhizobia due to high nitrogen fertilization.

4. They enhance the decomposition of soil, which leads to degradation of soil structure.

Nutrients are easily lost from soils through fixation; leaching or gas emission and can lead to reduced fertilizer efficiency. Alternative sources of plant nutrients have now become highly imperative especially for garden egg production in Enugu State. There is need for use of organic fertilizer that will play a better role in tackling soil infertility and produce food free of harmful chemicals, because, demand for food and agricultural products is increasing as the world's population is growing (to a projected 9.6 billion people in 2050) and incomes are rising in much of the developing world. To satisfy added consumer demand, by 2050 global food production will have to increase by $60 \%$ [3]. From the foregoing, this study was undertaken to assess organic fertilizer usage by garden egg farmers in Enugu State, Nigeria. The specific objectives were to:

- identify varieties of garden egg produced;

- ascertain the types of organic fertilizer used;

- assess pattern of organic fertilizer application;

- identify benefits of organic fertilizer use in garden egg production;

- identify the problem and constraints of using organic fertilizer in garden egg production.
The hypothesis that guided the study is: there is no significance influence of socio-economic characteristics on quantity of organic fertilizer use.

\section{MATERIALS AND METHODS}

The study was conducted in Enugu State, Nigeria. The population of the study consisted of all garden egg farmers in Enugu State. A multistage sampling technique was used in selecting respondents. The first involved the random selection of two agricultural zones from the six agricultural zones that make up the state. In the second stage, two blocks were selected from each zone using simple random sampling technique. This gave a total of four (4) blocks. The third stage comprised of the selection of two cells from each of the four blocks through simple random sampling technique giving a total of 8 cells. The fourth stage was the selection of 10 farmers from each cell giving overall respondents of 80 garden egg farmers.

Data for the study was collected using semistructured interview schedule administered to the respondents. To achieve objective 1 , respondents were asked to tick the variety of garden egg they cultivate from a list of garden egg varieties presented to them. Objective 2 was measured by asking respondents to indicate from a list the type of organic fertilizer used by them. Respondents were asked their pattern of application of organic fertilizer application to accomplish objective 3. A five-point Likert scale of; to no extent ( 0 ), to a small extent (1), to a moderate extent (2), to a large extent (3) and to a very large extent (4) was used to ascertain perceived benefits of organic fertilizer use in garden egg production. Variables with mean values of $\geq 2$ were accepted as perceived benefits of using organic fertilizer in garden egg production while variables with mean values of $<2$ were not accepted as perceived benefits of using organic fertilizer in garden egg production. To identify the constraints of using organic fertilizer in garden egg production, a five-point Likert scale of; not serious (0), serious (1), little serious (2), moderately serious (3) and very serious (4) was used. Variables with mean values of $\geq 2$ were accepted as constraints in using organic fertilizer in garden egg production while variables with mean values of $<2$ were not accepted as constraints in using organic fertilizer in garden egg production. 
Percentage, mean and standard deviation were used in the presentation of results. Hypothesis for the study was analysed using multiple regression. The regression equation was:

$$
\begin{aligned}
& Y=a_{1} b_{1}+a_{2} b_{2}+a_{3} b_{3}+a_{4} b_{4}+ \\
& +a_{5} b_{5}+a_{6} b_{6}+a_{7} b_{7}+U
\end{aligned}
$$

where $Y$ - quantity of organic fertilizer used (dependent variable);

$a$ - constant term;

$b$ - regression coefficients;

$x_{1}$ - age of farmers;

$x_{2}$ - farming experience;

$x_{3}$ - input cost per planting season;

$X_{4}$ - income per planting season;

$x_{5}$ - household size;

$x_{6}$ - marital status;

$x_{7}$ - sex of farmers;

$U$ - error term.

Data generated from the interview were analyzed using Statistical Product and Service Solutions (SPSS) version 20 at $5 \%$ level of probability.

\section{RESULTS AND DISCUSSION}

Socioeconomic characteristics of garden egg farmers. Table 1 show $58.8 \%$ of the farmers were female, a clear indication that female farmers had interest in garden egg production.

Women represent a crucial resource in agriculture and the rural economy through roles as farmers, labourers and traders [18].

The average age of farmers was 39 years, while $55.0 \%$ of the respondents were married and an average household size of 6 persons. The average age is a reflection that majority of the respondents were still within their economically active age and have the ability to synthesize and utilize information received on garden egg production. Additionally, having a good number of married people engaged in the garden egg production in the study area means that; the farmers could have more persons in the household to cater for and get help where necessary in carrying out their farm activities.

Table 1 - Socioeconomic characteristics of

\begin{tabular}{|c|c|c|}
\hline Parameters & $\%$ & $\operatorname{Mean}(\bar{x})$ \\
\hline \multicolumn{3}{|l|}{ Sex } \\
\hline Male & 41.3 & \\
\hline Female & 58.7 & \\
\hline \multicolumn{3}{|l|}{ Age } \\
\hline$<20$ & 6.3 & \multirow{6}{*}{39} \\
\hline $20-29$ & 22.5 & \\
\hline $30-39$ & 26.3 & \\
\hline $40-49$ & 22.4 & \\
\hline $50-59$ & 15.0 & \\
\hline 60 and above & 7.5 & \\
\hline \multicolumn{3}{|l|}{ Marital status } \\
\hline Single & 30.0 & \\
\hline Married & 55.0 & \\
\hline Divorced & 2.5 & \\
\hline Widowed & 12.5 & \\
\hline \multicolumn{3}{|l|}{ Household size } \\
\hline $1-5$ persons & 37.5 & \\
\hline $6-10$ persons & 56.3 & 6 \\
\hline $11-15$ persons & 6.3 & \\
\hline \multicolumn{3}{|c|}{ Farming experience (years) } \\
\hline $1-5$ & 48.8 & \multirow{5}{*}{7} \\
\hline $6-10$ & 42.5 & \\
\hline $11-15$ & 3.8 & \\
\hline $16-20$ & 3.8 & \\
\hline $21-25$ & 1.3 & \\
\hline \multicolumn{3}{|l|}{ Farm size (hectares) } \\
\hline$<0.5$ & 31.3 & \\
\hline $0.5-1$ & 43.7 & \\
\hline$>1$ & 25.0 & \\
\hline \multicolumn{3}{|c|}{ Input cost per planting season $(\mathrm{N})$} \\
\hline$\leq 25,000$ & 51.3 & \multirow{7}{*}{$88,026.88^{*}$} \\
\hline $25,001-50,000$ & 13.8 & \\
\hline $50,001-75,000$ & 6.3 & \\
\hline $75,001-100,000$ & 3.8 & \\
\hline $100,001-125,000$ & 6.3 & \\
\hline $125,001-150,000$ & 5.0 & \\
\hline$\geq 150,001$ & 13.8 & \\
\hline \multicolumn{3}{|c|}{ Income per planting season (N) } \\
\hline$\leq 25,000$ & 38.8 & \multirow{7}{*}{$128,162.50$} \\
\hline $25,001-50,000$ & 18.8 & \\
\hline $50,001-75,000$ & 1.3 & \\
\hline $75,001-100,000$ & 18.8 & \\
\hline $100,001-125,000$ & 2.5 & \\
\hline $125,001-150,000$ & 3.8 & \\
\hline$\geq 150,001$ & 16.3 & \\
\hline
\end{tabular}
respondents

Notes: $* 1$ Naira $=360$ USD 
However, with an average household size of 6 persons, there would be competition for the available resources in these households because large family size could negatively affect household food security. Moderate household size allows for efficient and effective planning and time management which encourages higher productivity.

An average of 7 years farming experience in the garden egg cultivation reveal that farmers have acquired some measure of knowledge by experience to adequately produce garden eggs and possibly make sales within their locality (see Table 1). On the average, farmers cultivated less than a hectare (0.98 hectare) bringing to light that farmers in the study were smallholder farmers. This agrees with the findings of [9] that Nigerian agriculture is essentially small scale in structure as over $90 \%$ of the farming population are holders of less than 6 hectares of land. This could further attest to the reason while the average input cost per planting season stood at $\mathrm{N} 88,026.88$ while income per planting season stood at $\mathrm{N} 128,162.50$. It can be inferred that these farmers are not having much returns on their investment on garden egg production.

Varieties of garden egg produced. As presented in Table 2, $52.5 \%$ of the respondents cultivate the Kumba specie (Solanum melongena var. depressum L.) of garden egg while $47.5 \%$ cultivate the Goli specie (Solanum melongena var. esculentum D).

The majority (95.0\%) of respondents cultivated garden egg during the raining season. Rain fed agriculture is dominant in Nigeria agriculture due to poor irrigation infrastructure. An implication that could be drawn from this is that, market value of garden egg may be low due to over production during the wet seasons. Data in Table 2 reveal that $77.5 \%$ of the respondents sourced planting materials personally.

The higher percentage of farmers having their planting materials themselves could be because of proper preservation of seedlings for planting at the end of a production season.

Mixed cropping (75.0\%) was highly upheld by farmers (Table 2). Mixed farming could be of great benefit to farmers because they have the flexibility of cultivating more than one crop. The benefit could be in the maximization of limited land available for cultivation. Also, it is a good way to generate more revenue and be food/finance secure in the advent of poor performance of a particular crop.

Table 2 - Cultivated varieties of garden egg

\begin{tabular}{|c|c|c|}
\hline Variables & $\%$ & $\begin{array}{c}\text { Mean } \\
(\bar{x})\end{array}$ \\
\hline \multicolumn{3}{|l|}{ Varieties of garden egg cultivated } \\
\hline Goli & 47.5 & \\
\hline Kumba & 52.5 & \\
\hline \multicolumn{3}{|l|}{ Planting season* } \\
\hline Dry season & 8.8 & \\
\hline Raining season & 95.0 & \\
\hline \multicolumn{3}{|l|}{ Source of planting material* } \\
\hline Self & 77.5 & \\
\hline Market & 38.8 & \\
\hline Neighbour & 16.3 & \\
\hline Ministry of agriculture & 6.3 & \\
\hline \multicolumn{3}{|l|}{ Planting system } \\
\hline Sole cropping & 25.0 & \\
\hline Mixed cropping & 75.0 & \\
\hline \multicolumn{3}{|l|}{ Frequency of harvest } \\
\hline 3-4 days interval & 45.0 & \multirow{2}{*}{5} \\
\hline 5-6 days interval & 55.0 & \\
\hline \multicolumn{3}{|l|}{ Suitable time for harvest } \\
\hline Morning & 75.0 & \\
\hline Afternoon & 1.3 & \\
\hline Evening & 12.5 & \\
\hline Anytime & 11.2 & \\
\hline \multicolumn{3}{|c|}{ Reasons for harvesting in the morning* } \\
\hline To avoid working under the sun & 62.5 & \\
\hline To meet up with marketers & 47.5 & \\
\hline It is a more convenient time & 38.8 & \\
\hline \multicolumn{3}{|l|}{ Duration for harvesting } \\
\hline Two months & 3.8 & \\
\hline Two and half months & 12.5 & \\
\hline Three months & 32.4 & \\
\hline Three and half months & 21.2 & \\
\hline Four months & 28.8 & \\
\hline Five months & 1.3 & \\
\hline \multicolumn{3}{|l|}{ Post-harvest operation * } \\
\hline Sorting & 37.5 & \\
\hline Bagging & 88.8 & \\
\hline \multicolumn{3}{|l|}{ Quantity harvested (KG) } \\
\hline 1,000 and below & 46.3 & \multirow{6}{*}{4927.38} \\
\hline $1,001-2,000$ & 12.5 & \\
\hline $2,001-3,000$ & 2.5 & \\
\hline $3,001-4,000$ & 2.5 & \\
\hline $4,001-5,000$ & 1.3 & \\
\hline Above 5,000 & 35.0 & \\
\hline
\end{tabular}

Notes: *multiple responses. 
Farmers in the study (55.0\%) found it more comfortable to harvest garden eggs on a 5-7 days interval (Table 2). This is contrary to [13] recommendation of 3-4 days harvesting interval. Morning hours (75.0 \%) was found to be suitable in the harvesting of garden eggs as most farmers would prefer harvesting in the early hours of the day to avoid working under high intensity of the sun. Furthermore, garden egg marketers preferred early morning trade so they could move their commodities early enough to meet market demands by consumers. Duration for garden egg harvesting was found to peak at 3 months $(32.4 \%)$ with the least $(1.3 \%)$ at 5 months. Thirty-seven percent of respondents sorted their garden egg fruits after harvesting with $88.8 \%$ bagging afterwards for onward sales to marketers. According to [15], goods produced and sold by farmers must be assembled, stored, transported, processed and delivered in the form needed, at the time and to the places desired by consumers.

On the average, farmers harvested 4,927 $\mathrm{kg}$ in a planting season (Table 2). This is rather low. A number of different factors can cause agricultural productivity to increase or decrease. It is important to note that productivity is not an absolute measure, but rather a reflection of the ratio between inputs and outputs. For agricultural productivity innovation is a key factor. If farmers want to increase their productivity, they need to farm smarter, by using innovative farm management systems.

Types of organic fertilizer used. Farmyard manure $(97.5 \%)$ ranked highest among the organic fertilizer used by farmers (Table 3). Green manure was less patronized thus it accounted for $7.5 \%$. Farmyard manure may have been engaged by farmers because it is fast absorbed by plants as opposed to green manure. More so, respondents sourced their organic manure from poultry waste $(63.8 \%)$ while green manure stood at seven percent $(7.0 \%)$.

Poultry manure could be sourced more by respondents due to it ready availability and the ease with which it is applied. However, the average amount spent by respondents in the purchase of organic manure in a planting season was N 57,372.73. This shows that respondents did not have enough resources to purchase organic manure. This in the long run could affect their overall yield.
Table 3 - Types of organic fertilizer used

\begin{tabular}{|c|c|c|}
\hline Variables & $\%$ & $\begin{array}{c}\text { Mean } \\
(\bar{x})\end{array}$ \\
\hline \multicolumn{3}{|c|}{ Awareness of organic fertilizer } \\
\hline Yes & 100 & \\
\hline \multicolumn{3}{|l|}{ Use of organic fertilizer } \\
\hline Yes & 100 & \\
\hline \multicolumn{3}{|c|}{ Duration of use of organic fertilizer (years) } \\
\hline $1-5$ & 50.0 & \multirow{4}{*}{6.43} \\
\hline $6-10$ & 41.2 & \\
\hline $11-15$ & 5.0 & \\
\hline $16-20$ & 3.8 & \\
\hline \multicolumn{3}{|c|}{ Type of organic fertilizer used* } \\
\hline Farmyard manure & 97.5 & \\
\hline Green manure & 7.5 & \\
\hline \multicolumn{3}{|c|}{ Source of manure* } \\
\hline Poultry & 63.8 & \\
\hline Sheep and goat & 20.0 & \\
\hline Pig & 28.8 & \\
\hline Green compost & 7.5 & \\
\hline \multicolumn{3}{|c|}{ Cost of organic fertilizer/planting season ( } \\
\hline 25,000 and below & 47.3 & \multirow{5}{*}{57372.73} \\
\hline $25,001-50,000$ & 23.6 & \\
\hline $50,001-75,000$ & 9.1 & \\
\hline $75,001-100,000$ & 7.3 & \\
\hline 100,001 and above & 12.7 & \\
\hline
\end{tabular}

Notes: $* 1$ Naira $=360$ USD

Pattern of organic fertilizer application. Respondents (52.5\%) applied less than $500 \mathrm{~kg}$ quantity of organic fertilizer per planting season with an overall average of $1665 \mathrm{~kg}$ (Table 4). By implication, farmers applied far below what is expected. Authors [7] are of the view that 10 tonnes per hectare application of organic fertilizer will ensure optimum growth in vegetable production.

Table 4 - Pattern of organic fertilizer application

\begin{tabular}{|c|c|c|}
\hline Variables & $\%$ & $\begin{array}{c}\text { Mean } \\
(\bar{x})\end{array}$ \\
\hline \multicolumn{3}{|l|}{ Quantity of fertilizer applied (kg) } \\
\hline$<500$ & 52.5 & \multirow{5}{*}{1665.62} \\
\hline $501-1000$ & 8.8 & \\
\hline $1001-1500$ & 13.8 & \\
\hline $1501-2000$ & 17.5 & \\
\hline Above 2000 & 7.5 & \\
\hline \multicolumn{3}{|l|}{ Total number of application per season } \\
\hline 1 & 36.3 & \\
\hline 2 & 40.0 & \\
\hline 3 & 23.8 & \\
\hline \multicolumn{3}{|l|}{ Nursery stage } \\
\hline Once & 55.0 & \\
\hline
\end{tabular}




\begin{tabular}{|c|c|c|}
\hline Variables & $\%$ & $\begin{array}{c}\text { Mean } \\
(\bar{x})\end{array}$ \\
\hline \multicolumn{3}{|l|}{ Vegetative stage } \\
\hline Once & 65.0 & \\
\hline Twice & 8.8 & \\
\hline Thrice & 1.3 & \\
\hline \multicolumn{3}{|l|}{ Flowering stage } \\
\hline Once & 22.5 & \\
\hline \multicolumn{3}{|l|}{ Fruiting stage } \\
\hline Once & 23.8 & \\
\hline \multicolumn{3}{|l|}{ Method of application* } \\
\hline Broadcast method & 32.5 & \\
\hline Side-dressing method & 7.5 & \\
\hline Ring method & 61.3 & \\
\hline \multicolumn{3}{|l|}{ Treatment of organic fertilizer } \\
\hline No & 77.5 & \\
\hline \multicolumn{3}{|c|}{ Reasons for treating organic fertilizer $(n=18)^{*}$} \\
\hline To reduce odorous nature of manure & 8.8 & \\
\hline Easy application & 13.8 & \\
\hline Avoid pest infection & 2.5 & \\
\hline To improve the quality of the manure & 5.0 & \\
\hline \multicolumn{3}{|l|}{ Treatment method $(\mathrm{n}=18)^{*}$} \\
\hline Sun dry & 77.8 & \\
\hline Mix with wood ash & 27.8 & \\
\hline \multicolumn{3}{|l|}{ Storage of organic fertilizer } \\
\hline No storage & 22.5 & \\
\hline In bags & 50.0 & \\
\hline In an uncompleted building & 12.5 & \\
\hline In a kraal pen & 12.5 & \\
\hline In pit & 2.5 & \\
\hline
\end{tabular}

Notes: *multiple responses.

Their assertion is further corroborated by those of Food and Agriculture Organization (FAO) that 33t/ha of cow dung, $19 \mathrm{t} /$ ha of sheep manure and $11 \mathrm{t} / \mathrm{ha}$ of air-dried poultry manure be used by farmers.

A greater proportion (40.0\%) of the respondents applied organic fertilizer twice per planting season in various stages of application (Table 4). Some (55.0\%) respondents applied organic fertilizer at the nursery stage with the highest application of organic fertilizer being at the vegetative state $(75.1 \%)$. Methods of organic fertilizer application ranged from broadcasting $(32.5 \%)$ to ring method (61.3\%). Ring method of application would have been adopted most because it limits weed access to nutrients released when the organic fertilizer begins to act. Omotosho and Shittu (2007) opined that ring method of fertilizer application is effective for the growth and yield of plant.

Table 4 reveals that $77.5 \%$ of the respondents do not treat organic fertilizer before use. This might

not be unconnected with inadequate knowledge on the need to do so. Further deductions from this outcome could be that the garden egg farmers have poor contact with extension agents as such lack some important knowledge with respect to proper handling and use of organic fertilizers. Furthermore, $50.0 \%$ of the respondents stored organic fertilizer in bags, an indication that farmers in the study used crude storage methods to keep their organic fertilizer. This may be due to the high cost of ideal storage materials. Organic fertilizer could have less effect on crops due to deterioration occasioned from poor storage.

Benefits of organic fertilizer use in garden egg production. Entries in Table 5 reveal major perceived benefits of using organic fertilizer in growing garden egg to be; its environment friendly nature $(2.99 \pm 1.23)$ as well as improvement of soil fertility ( $2.95 \pm 1.12$ ). These findings are consistent with previous studies by $[16,20$, 22] that application of organic matter to the soil could also improve aggregate stability and resistance to soil compaction, enhanced fertility and reduced nutrient leaching, increased biological activity, enhance water retention capacity and reduction of greenhouse gases by soil carbon sequestration.

Table 5 - Perceived benefit of organic fertilizer in garden egg production

\begin{tabular}{|c|c|c|}
\hline Variables & $\begin{array}{c}\text { Mean } \\
(\bar{x})\end{array}$ & S. D. \\
\hline \multicolumn{3}{|l|}{ Environmental benefit } \\
\hline Environmental friendly & $2.99 *$ & 1.23 \\
\hline Improve soil fertility & $2.95^{*}$ & 1.12 \\
\hline Reduce soil degradation & $2.70^{*}$ & 1.47 \\
\hline Neutralize soil acidity & $2.09^{*}$ & 1.43 \\
\hline Reduce environment pollution & $2.03^{*}$ & 1.60 \\
\hline Improve water holding capacity & 1.36 & 1.42 \\
\hline $\begin{array}{r}\begin{array}{r}\text { Promote growth of beneficial } \\
\text { microbes }\end{array} \\
\end{array}$ & 1.11 & 1.45 \\
\hline \multicolumn{3}{|l|}{ Health benefit } \\
\hline $\begin{array}{r}\text { Organic foods contain higher level of } \\
\text { vitamin }\end{array}$ & $3.09 *$ & 1.05 \\
\hline Chemical free agricultural product & $2.40^{*}$ & 1.27 \\
\hline $\begin{array}{r}\text { Highly nutritional value of organic } \\
\text { products }\end{array}$ & $2.26^{*}$ & 1.43 \\
\hline \multicolumn{3}{|l|}{ Economic benefit } \\
\hline Attract higher market price & $2.83^{*}$ & 1.98 \\
\hline Lowers farm input cost & $2.63^{*}$ & 1.05 \\
\hline Profit maximization & $2.50^{*}$ & 1.20 \\
\hline Prolong shelf life of garden egg & $2.11^{*}$ & 1.52 \\
\hline Increase farmers income & 1.61 & 1.49 \\
\hline
\end{tabular}


Constraints of using organic fertilizer in garden egg production. The most profound problems and constraints affecting garden egg production as identified in the study include slow effect of organic fertilizers on crops $(2.12 \pm 1.43)$, odorous nature of organic fertilizer $(2.06 \pm 1.28)$, difficulty in collection and handling of organic fertilizer (2.72 \pm 1.03$)$, time consuming nature in its use $(2.71 \pm 1.12)$, and inadequate skill in handling organic fertilizers $(2.04 \pm 1.49)$. Consistent with previous studies by [1,4], the slow effect of organic fertilizer on crops can be an advantage and disadvantage at the same time because while the slowness may decrease current output, the long lasting effect of organic fertilizer due to the slow release of minerals may help decrease future cost of production and increase future output. Also, author [2] found that offensive odour, difficulty in transporting and doubtful efficacy is the constraints mitigating against the use of organic fertilizer.

Table 6 - Constraints of using organic fertilizer

\begin{tabular}{|l|c|c|}
\hline \multicolumn{1}{|c|}{ Variables } & $\begin{array}{c}\text { Mean } \\
(\bar{x})\end{array}$ & S. D. \\
\hline $\begin{array}{l}\text { Difficulty in collection and handling of } \\
\text { organic fertilizer }\end{array}$ & $2.72^{*}$ & 1.03 \\
\hline Time consuming & $2.71^{*}$ & 1.12 \\
\hline Slow effect & $2.12^{*}$ & 1.43 \\
\hline Odorous nature & $2.06^{*}$ & 1.28 \\
\hline $\begin{array}{l}\text { Inadequate skills in handling organic } \\
\text { fertilizer }\end{array}$ & $2.04^{*}$ & 1.49 \\
\hline Labour intensive & $2.01^{*}$ & 1.18 \\
\hline $\begin{array}{l}\text { Difficulty in transporting organic fer- } \\
\text { tilizer }\end{array}$ & 1.75 & 1.38 \\
\hline Lack of storage facilities & 1.59 & 1.33 \\
\hline Weed emergence & 1.28 & 1.28 \\
\hline Difficult to attain nutrient & 1.31 & 1.21 \\
\hline
\end{tabular}

Influence of socioeconomic characteristics on quantity of organic fertilizer use. The result of the multiple regression analysis presented in Table 7 shows a significant influence $(\mathrm{p}<0.05)$ between the socio-economic characteristics of farmers and the quantity of organic fertilizer used.

The $\mathrm{R}$ square $\left(\mathrm{R}^{2}\right)$ and $\mathrm{R}$ square adjusted value were 0.829 and 0.812 , respectively. This shows that about $82 \%$ of the variance in the quantity of organic fertilizer applied by farmers was explained by the socio-economic variables included in the model. Variables that had significant influence on organic fertilizer use were: income per planting season $(t=6.695 ; \mathrm{p}<0.000)$, input cost per season of farmers $(\mathrm{t}=2.365 ; \mathrm{p}<0.021)$ and sex $(\mathrm{t}=-2.264 ; \mathrm{p}<0.027)$. Therefore, the null hypothesis was rejected for these variables.

Table 7 - Influence of socio-economic characteristics on quantity of organic fertilizer use

\begin{tabular}{|l|r|r|r|r|}
\hline \multirow{2}{*}{ Model } & \multicolumn{2}{|c|}{$\begin{array}{c}\text { Unstandardized } \\
\text { Coefficients }\end{array}$} & $\begin{array}{c}\text { Standardized } \\
\text { Coefficients }\end{array}$ & \multirow{2}{*}{ T } \\
\cline { 2 - 4 } & \multicolumn{1}{c|}{ B } & Std. Error & \multicolumn{1}{|c|}{ Beta } & \\
\hline Constant & 793.055 & 1054.047 & & 0.752 \\
\hline $\begin{array}{l}\text { Age of } \\
\text { farmer }\end{array}$ & 8.983 & 24.264 & 0.024 & 0.370 \\
\hline $\begin{array}{l}\text { Farming } \\
\text { experience }\end{array}$ & -56.621 & 76.012 & -0.051 & -0.745 \\
\hline $\begin{array}{l}\text { Input cost } \\
\text { per } \\
\text { planting } \\
\text { season }\end{array}$ & 0.008 & 0.003 & 0.259 & $2.365^{*}$ \\
\hline $\begin{array}{l}\text { Income } \\
\text { per } \\
\text { planting } \\
\text { season }\end{array}$ & 0.012 & 0.002 & & \\
\hline $\begin{array}{l}\text { Household } \\
\text { size }\end{array}$ & -63.055 & 106.224 & 0.707 & $6.695^{*}$ \\
\hline $\begin{array}{l}\text { Marital } \\
\text { status }\end{array}$ & -773.321 & 536.926 & -0.031 & -0.594 \\
\hline $\begin{array}{l}\text { Sex of } \\
\text { farmers }\end{array}$ & -1335.549 & 589.968 & -0.136 & $-2.264^{*}$ \\
\hline
\end{tabular}

Notes: Predictors (Constant) - Socio-economic characteristics of garden egg farmers; Dependent Variable: quantity of organic fertilizer use; R square - 0.829 ; R square adjusted- 0.812, F- 49.813, $p<0.05$.

Deductions from these significant variables would mean the more income and input per planting season, the more quantity of organic fertilizer would be used among garden egg farmers. Farmers tend to increase their input level to have an increased yield when they have more purchasing power. Age and farming experience had no significant influence on the quantity of organic fertilizer used by garden egg farmers. Hence the null hypothesis was accepted for these variables.

\section{CONCLUSIONS}

It is evident from the study that garden egg farmers in the study area used organic fertilizers. Organic fertilizer use will adequately enhance the production of garden egg in Enugu State of Nigeria. Nonetheless, the quantity applied was below the recommended rate for optimum yield. Likewise, the pattern of storage of organic fertilizer in 
the study area was archaic. Organic fertilizer could have less effect on crops due to deterioration occasioned from poor storage. It is therefore recommended that farmers be granted credits to purchase needed equipment to effectively handle the storage and use of organic fertilizer. Furthermore, extension services that will teach them the required skills in the handling and use of organic fertilizer should be put in place.

\section{REFERENCES}

1. Aderinoye-Abdulwahab, S. A., \& Salami, S. T. (2017). Assessment of organic fertilizer usage by vegetable farmers in Asa Local Government area of Kwara State, Nigeria. Agrosearch, 17(1), 101. doi: 10.4314/agrosh.v17i1.8

2. Ajewole, O. C. (2010). Farmers' response to adoption of commercially available organic fertilizers in Oyo state, Nigeria. African Journal of Agricultural Research, 5(18), 2497-2503.

3. Alexandratos, N., \& Bruinsma, J. (2012). World Agriculture Towards 2030/2050: the 2012 revision. Retrieved from http://www.fao.org/3/a-ap106e.pdf

4. Alimi, T, Aiewole, O. C., Olubode-Awosola, O. O. \& Idowu, E.O. (2006). Economic rationale of commercial organic fertilizer technology in vegetable production in Osun State of Nigeria. Journal of Applied Horticulture, 8(2), 159-164.

5. Chen, N. C., (2001). Eggplant Seed Production. Retrieved from http://203.64.245.61/web_crops/eggplant/eggplantseed.pdf

6. Danqua-Jones, A. (2000). Variation and correlation among agronomic traits of Garden egg (Solanium gilo Radii) in Gana. International Journal of Science and Nature, 3(2), 373-379.

7. Ilodibia, C. V., \& Chukwuma, M. U. (2015). Effects of Application of Different Rates of Poultry Manure on the Growth and Yield of Tomato (Lycopersicum esculentum Mill.). Journal of Agronomy, 14(4), 251-253. doi: 10.3923/ja.2015.251.253

8. Koning, N., Heerink, N., \& Kauffman, S. (2001). Food Insecurity, Soil Degradation and Agricultural Markets in West Africa: Why Current Policy Approaches Fail. Oxford Development Studies, 29(2), 189-207. doi: 10.1080/13600810124747

9. Law-Ogbomo, K. E., \& Osaigbovo, A. U. (2018). Productivity response of garden egg (Solanum melongena L.) to plant population and fertilizer. Acta Horticulturae, 1225, 145-150. doi: 10.17660/actahortic.2018.1225.19

10. Mairura, F. S., Mugendi, D. N., Mwanje, J. I., Ramisch, J. J., Mbugua, P. K., \& Chianu, J. N. (2008). Scientific evaluation of smallholder land use knowledge in Central Kenya. Land Degradation \& Development, 19(1), 77-90. doi: 10.1002/ldr.815

11. Norman, J. C. (1992). Tropical Vegetable Crops. Luyengo: Arthur stockwell Ltd.

12. Ojiem, J. (2006). Exploring Socio-ecological Niches for Legumes in Western Kenya smallholder farming systems (Doctoral thesis), Wageningen University. Retrieved from https://www.researchgate.net/publication/40112136_Exploring_socioecological_niches_for_legumes_in_western_Kenya_smallholder_farming_systems

13. Ojo, D. (2011). Integrated Harvesting Techniques for African Egg Plant (Solanum macrocarpon L., cv. Igbagba). American Journal of Experimental Agriculture, 1(4), 458-465. doi: 10.9734/ajea/2011/558

14. Omotosho, S. O. and Shittu, O. S. (2007). Effect of NPK Fertilizer Rates and Method of Application on Growth and Yield of Okra (Abelmoschus esculentus (L.) Moench) at Ado-Ekiti Southwestern, Nigeria. International Journal of Agricultural Research, 2(7), 614-619. doi: 10.3923/ijar.2007.614.619 
15. Onunka, B. N. (2005). A Survey on the Adoption of Sweet Potato (Ipomoea batatas) Production Technologies in Abia State (Master's dissertation), Abia State University, Uturu, Nigeria.

16. Overstreet, L. F., \& DeJong-Huges, J. (n. d.). The Importance of Soil Organic Matter in Cropping Systems of the Northern Great Plains. Retrieved from https://www.certifiedcropadviser.org/files/certifications/certified/education/selfstudy/exam-pdfs/154.pdf

17. Pallabi, M., Debiprasad, D. (2014). Rejuvenation of biofertilizer for sustainable agriculture and economic development. Consilience: The Journal of Sustainable Development, 11(1), 41-61.

18. Peterman, A., Quisumbing, A., Behrman, J., \& Nkonya, E. (2011). Understanding the Complexities Surrounding Gender Differences in Agricultural Productivity in Nigeria and Uganda. Journal of Development Studies, 47(10), 1482-1509. doi: 10.1080/00220388.2010.536222

19. Sabo, E., \& Dia, Y. Z. (2009). Awareness and effectiveness of vegetable technology information packages by vegetable farmers in Adamawa State, Nigeria. African Journal of Agricultural Research, 4(2), 65-70.

20. Spaccini, R., Piccolo, A., Mbagwu, J. S. C., Zena Teshale, A., \& Igwe, C. A. (2006). Influence of the addition of organic residues on carbohydrate content and structural stability of some highland soils in Ethiopia. Soil Use and Management, 18(4), 404-411. doi: 10.1111/j.14752743.2002.tb00259.x

21. The Tide. (2017, April 7). Enugu farmers receive lime for soil fertility. Retrieved from http://www.thetidenewsonline.com/2017/04/07/enugu-farmers-receive-lime-for-soil-fertility

22. Usman, S. \& Kundiri, A.M. (2016). Values of organic materials as fertilizers to northern Nigerian crop production systems. Journal of Soil Science and Environmental Management, 7(12), 204211. doi: $10.5897 /$ jssem 2015.0532 